\title{
PREVENTIVE MEDICINE IS A CORNERSTONE OF HEALTH PROMOTION
}

Polunina NV, Pivovarov YuP, Milushkina OYu $\bowtie$

Faculty of Pediatrics, Pirogov Russian National Research Medical University, Moscow

Preventive healthcare encompasses a broad range of medical and social interventions aimed at protecting and promoting public health, averting diseases or reducing the risk of their development. Preventive measures seek to create conducive working conditions and good resting environment, promote physical exercise, healthy nutrition, personal hygiene and sanitation, and eventually improve the well-being of the population. This article reviews a number of research works into the impact of various factors on the health of adults and children. Based on their findings, we propose measures for reducing the effects of harmful factors and incorporating positive factors in our daily life. The model of preventive healthcare adopted in Russia is aimed at preventing adult and child morbidity, increasing life expectancy, promoting positive attitude to health, and creating safe environment.

Keywords: prevention, health factors, adults, children, healthy lifestyle

$\triangle$ Correspondence should be addressed: Olga Yu. Milushkina

Ostrovityanova 1, Moscow, 117997; olmilushkina@mail.ru

Received: 04.09.2018 Accepted: 05.10.2018

DOI: $10.24075 /$ brsmu.2018.058

\section{ПРОФИЛАКТИЧЕСКАЯ МЕДИЦИНА - ОСНОВА СОХРАНЕНИЯ ЗДОРОВЬЯ НАСЕЛЕНИЯ}

\author{
Н. В. Полунина, Ю. П. Пивоваров, О. Ю. Милушкина \\ Педиатрический факультет, Российский национальный исследовательский университет имени Н. И. Пирогова, Москва
}

\begin{abstract}
Профилактическая медицина - это комплекс медико-социальных мероприятий, направленных на охрану и укрепление здоровья населения, предупреждение возникновения заболеваний, устранение факторов риска ихвозникновения. Она включает как медицинские мероприятия, так и создание благоприятных условий труда и быта, отдыха и физического воспитания, организацию здорового и полноценного питания различных групп, оздоровление окружающей среды, повышение благосостояния и улучшение условий жизни населения. В статье представлен обзор научных исследований по оценке воздействия на здоровье населения, в том числе детского, различных факторов внешней среды, предложены конкретные мероприятия по профилактике, опирающиеся на эти исследования, и меры, которые разрабатываются по нивелированию негативных для здоровья факторов и активному внедрению в повседневную жизнь позитивных факторов. Профилактическая модель современного здравоохранения России направлена на предупреждение развития заболеваний детского и взрослого населения, увеличение продолжительностижизниграждан, формирование установок к здоровому образу жизни и создание безопасных условий окружающей среды.
\end{abstract}

Ключевые слова: профилактика, формирующие здоровье факторы, взрослое население, детское население, здоровый образ жизни

$\varangle$ Для корреспонденции: Ольга Юрьевна Милушкина ул. Островитянова, д. 1, г. Москва, 117997; olmilushkina@mail.ru

Статья получена: 04.09.2018 Статья принята к печати: 05.10.2018

DOI: $10.24075 /$ vrgmu.2018.058

\section{Importance of joint socio-economic and clinical measures in preventive healthcare}

One of the central challenges that our country has to address is protection and promotion of public health [1, 2]. In Russia, there has always been a focus on finding effective solutions to the problem of public health improvement. Among the principles underpinning the public healthcare system in Russia are prevention and social work aimed at maintaining the health of its young and old citizens [3].

Social and preventive healthcare encompasses a broad range of social, economic and clinical interventions aimed at protecting and maintaining public health. Prevention goes beyond clinical interventions, vaccination, good hygiene routine, adoption of sanitary acts, etc. It has many different aspects that should be promoted by the state, changing the mindset of the public in favor of healthy lifestyle.
Srategies for prevention should include social, economic, clinical, and organizational interventions. Prevention targets all aspects of social life, including working and living conditions, leisure, physical education, nutrition, environmental factors, and eventually the well-being of the population, contributing to the harmonious development of physical and mental capacities of an individual. Prevention transcends the boundaries of medicine and healthcare systems and becomes a social strategy of the state.

Among measures for diseases prevention are psychological, biological, social and economic interventions that reduce the risk of giving in to unhealthy choices, protect against occupational hazards and improve living conditions.

Classification of measures for disease prevention into socioeconomic, psycho-social, socio-hygienic and medical is quite arbitrary. Much more important is the result of their application: good public health statistics that can be achieved by joining the 
efforts of the state and society and implementing all aspects of the preventive healthcare strategy.

\section{The history of preventive medicine}

The concept of preventive healthcare emerged when society started to realize the significance of averting diseases and their complications. As knowledge was gradually accumulated, people established requirements for the quality of potable water, food, indoor air in residential and commercial buildings, artificial and natural lighting, elaborated radiation safety guidelines, standards of personal hygiene, recommendations for sleep-wake routine, controlled cold exposure, nutrition, physical exercise, etc. [4, 5]. Research has demonstrated a mutual impact between the environment and humans, as well as the role of social factors in maintaining public health and preventing diseases, which helped to identify the main areas of focus for preventive healthcare practiced in communities [6-8].

In March 1919 preventive healthcare defined as "a broad scope of recreational and sanitary measures aimed at preventing the risk of diseases" was declared a central challenge of Russian healthcare system. It still remains one of its major areas of focus. According to official documents, this strategy implemented as a complex of socio-economic and medical interventions is aimed at preventing and eradicating diseases, including infections, and increasing life expectancy [1].

Considering the deteriorating ecology, negative demographic trends and high incidence of non-infectious diseases among different subpopulations, development of measures for protecting and promoting public health remains a top-priority task.

In this light, prevention becomes a fundamental principle underlying the social policy of the state underpinning strategies for protecting and promoting public health.

Prevention (or prophylaxis, from Greek prophylaktikos) is a range of activities exercised by state agencies and healthcare providers aimed at identifying causes of diseases or injuries and neutralizing or eliminating their negative impact on humans. Prevention can be classified into personal and public; primary, which fights the actual cause of a disease, and secondary, which promotes factors reducing the risk of complications of an inflicted injury or disease.

\section{The role of hygiene and social factors in public health}

Preventive interventions can be implemented only after the role of different factors in promoting public health has been established. Factors that negatively affect public health should be neutralized and positive factors should be incorporated into everyday life. To this end, studies of social hygiene are conducted both abroad and here, in Russia, at the Faculty of Hygiene, Public Health and Healthcare Economics of Pirogov Russian National Research Medical University, and their findings are successfully implemented. Research into public health and the factors that affect it should be continuous and account for the constantly changing environment.

Based on the published literature, factors affecting public health can be distributed into four groups:

1) socio-economic situation and lifestyle;

2) environment;

3) biological factors;

4) activity of healthcare providers.

\section{Lifestyle}

Lifestyle has the most serious impact on human health, its contribution being as high as $50 \%$ in comparison with other factors. The contribution of environmental pollution is 20-25\%; biological factors, $15-20 \%$, and $10-15 \%$ are the result of activities exerted by healthcare agencies and providers. These figures are consistent with the data reported by other authors [9].

The factors mentioned above can have both negative and positive impact on health increasing or reducing the risk of developing a disease.

Protection and promotion of health are important not only for individuals with compromised health $[10,11]$, but for the healthy ones as well [12-17] because projects seeking to improve the health of different subpopulations contribute to economic growth, ensure social stability and safety.

There are over 40 definitions of "lifestyle", including those describing healthy and unhealthy behaviors. Most often, lifestyle is a cumulative concept that encompasses hygienerelated, social, economic, clinical and psychological aspects. There is another brief but very accurate definition of lifestyle as a public phenomenon closely related to the mode of production characterizing "a definite form of activity of ... individuals, a definite form of expressing their life, a definite mode of life on their part" [18].

In other words, lifestyle is a historically shaped activity exerted by an individual, a group of people, or a population in general in material and immaterial spheres of life. Lifestyle is studied by psychologists, psychiatrists, philosophers, legislators, sociologists, and doctors who look at human motivation and behavior from different perspectives noticing its direct impact on health.

Research studies yielded sufficient data to gauge the impact of social factors on the life of individuals and groups of people. A correlation has been established between social hygiene and human health. It was noticed that in the identical social settings the health of individuals and the activity they exert can vary, so the studies that followed focused on different aspects of lifestyle and their role in public health. Two types of activities (occupational and leisure) have been identified that can be further classified into professional, social, political, cognitive, cultural, educational, communal, and others. There are a lot of specific criteria that help to differentiate these activity types from one another, but at the same time the latter are closely related and complement each other, allowing us to perform a comprehensive analysis of lifestyle and identify its impact on the health of a studied cohort.

\section{Work}

Work is an essential part of our lives which affects both our lifestyle and health. Among the most important work-related factors that affect human health are the length of service, an atmosphere at workplace, and occupational hazards [12, 19-21].

There is a reliable direct correlation between the length of service and an employee's health $(r=+0.639 ; m= \pm 0.08)$; the length of service also correlates with the age of an employee $(r=+0.714 ; m= \pm 0.09)$ and an atmosphere at workplace $(r=+0.513 ; m= \pm 0.07)$. In older employees, the presence of chronic conditions correlates with their age $(r=+0.924$; $m= \pm 0.03 ; p<0.01)$ and an atmosphere at workplace $(r=+0.708 ; m= \pm 0.04 ; p<0.01)$.

Because an employee's health deteriorates with age and depends on the length of service, factors affecting occupational health should be thoroughly studied. The employees who work in a positive, friendly atmosphere are not susceptible to the negative impact of service length [17, 22, 23].

Exposure to occupational hazards also affect employees' health. On average, $25-35 \%$ of women and $57-63 \%$ of men 
work in hazardous industries and are exposed to dangerous chemicals, extreme temperatures or radiation, have to spend a lot of time in constrained postures, etc. Long-term exposure to poor working conditions and occupational hazards is particularly dangerous for human health.

Intensive daily computer work lasting for over 6 hours can compromise an employee's health, too [22, 24]. Today, computers, mobile phones and other gadgets are ubiquitous, while their harmful effect on the organism is yet to be understood. Exposure to a combination of several occupational risk factors aggravates the situation. Of 100 respondents, 37 to 42 report exposure to 2 to 3 hazards in their workplace; men are exposed to a combination of occupational hazards more often than women.

Another serious problem faced by the society is gadget addiction. On a typical school day, schoolchildren spend 7 hours using electronic gadgets; male university students, 8.5 hours a day; and female university students, 10 hours a day. The time children and teenagers spend using their gadgets taking no breaks is 1.5 to 2 hours. Gadgets are often used outside the classroom, especially in public transport, school halls, recreational facilities, and other popular spots where wi$\mathrm{fi}$ is available. As a result, both schoolchildren and university students complain of headache, eye strain, and blurred vision, i.e. asthenopia. University students tend to complain more of pain in the eyes and blurred vision $(p<0.05)$. Ocular fatigue depends on the frequency of computer (Pearson's contingency coefficient is $0.7 ; p<0.001$ ), laptop (Pearson's contingency coefficient is $0.7 ; p<0.001$ ) or tablet use (Pearson's contingency coefficient is $0.6 ; p<0.001$ ) [25].

\section{Leisure}

Time spent off work is an important part of our lives. It is time for family reunions, housework, rest, and other leisure activities.

The analysis of housing conditions, including the type of a flat or apartment, the number of people who live in it, its internal layout, density of occupation, availability of store rooms, public amenities and overall comfort shows that satisfaction with living conditions is an important component of a person's mental and emotional state. Among the respondents living in objectively poor conditions $21.3 \%$ are quite satisfied with their housing, while among those living in objectively good conditions $27.1 \%$ feel dissatisfied [13, 26-31]. The degree of satisfaction is the major factor that affects health since it is a component of a person's mental and emotional state $(r=+0.416 ; m= \pm 0.06$; $p<0,01)$.

Studies demonstrate that only $18-23 \%$ of the respondents are satisfied with their income, whereas $26-32 \%$ are not happy with it. On the whole, 52-56\% of working age respondents confess they live paycheck-to-paycheck. However, 70-74\% of the surveyed families have a car, $68-72 \%$ have a country house, and $38-42 \%$ spend their vacations outside the area of residence. This means than more than half of the working-age population can be described as middle-income.

The mental and emotional state has a serious impact on our lifestyle and health and is a product of relationships within a family, family conflicts, traditions and rituals. It shows to what extent a person is satisfied with an atmosphere in their family. Financial status and living conditions also contribute to our emotional state. The majority of the surveyed families describe their mental and emotional state as good (28-32\%) and satisfactory (49-53\%). Families whose members complain of emotional distress report frequent arguments caused by poor living conditions, low income, disagreement on how to raise children or grandchildren, alcohol abuse, and bad habits. Among younger respondents aged 30 to 40 years, 21-23\% admit having problems they find hard to solve; however, only $18-19 \%$ of older respondents aged $40-50$ years and $16-17 \%$ of people aged 50 to 60 years believe their problems are really difficult. There is a direct correlation between a person's health and his/her mental and emotional state $(r=+0.328$; $m= \pm 0.05 ; p<0.01$ )

Regression analysis has revealed associations between medical, biological and social factors and the health of children and teenagers. The following standardized regression coefficients were computed: use of medications during pregnancy $(0.36)$, number of births a woman had $(-0.27)$, family composition (0.27), paternal education (0.25), conflicts in the family (0.24) [32].

Because the mental and emotional state has a profound impact on health, studies have been conducted to identify and analyze the factors that produce a positive effect. The results show that the majority of respondents list a stable job (80-84\%), stable income (78-80\%), good living conditions (70-74\%), a good atmosphere in a family (64-68\%), lack of conflicts in a family (52-56\%), and satisfaction with leisure time activities (44-48\%) among the factors they find uplifting. There are significant differences between men and women in terms of ranking the importance of the mentioned factors. Men think that a stable job and good relationships in a family are more important, while women rank stable income and good living conditions higher. Older respondents value good health more, as well as good relationship in a family, and believe the absence of conflicts is important. In general, the respondents give 2-3 reasons that promote positive atmosphere in a family.

\section{Health awareness}

The willingness of a person to use medical services and follow medical advice has a direct impact on health. Therefore, prevention should focus on the promotion of healthy habits and stimulation of positive attitude towards medicine in general. Taking care of your health implies regular medical checkups, adherence to medical regimens and recommendations, getting rid of bad habits, improving health literacy, etc. Health awareness is shaped by an attitude to nutrition, sports and physical exercise, alcohol, smoking, keeping fit, consultations with a doctor when feeling ill, undergoing regular medical checkups, hygiene, daily routine, and other things [31, 33-37].

These aspects of health awareness depend on a person's cultural background, education, outlook on life, living conditions, well-being, the state of public healthcare in a given country, etc. Among the factors that directly affect our health the leading role is played by health literacy, which is about being interested in obtaining information about health, risk factors that affect it, and disease prevention strategies.

Health literacy can be improved by reading specialized literature, watching or listening to TV or radio programs about health, risk factors or prevention strategies, or attending lectures delivered by healthcare professionals [20, 27, 28, 38-40].

Studies show that only $27-38$ of 100 people are willing to seek such information. Among patients with chronic conditions this number is higher (65-70 individuals out of 100). Increased interest in medical knowledge is usually the result of a person's health status. Patients with chronic conditions read medical literature twice more often in comparison with individuals who do not have a chronic disease.

Of every 100 respondents who like to educate themselves about health-related issues, 68.1 people read popular science 
literature, 9.4 people read specialized medical literature, 41.6 watch TV programs about health, 15.2 people listen to similar programs on the radio, 11.2 people ask their doctors, and 1.6 people attend specialized lectures. These data indicate the need for educational projects stimulating interest in popular science literature and TV or radio programs aimed at maintaining public health.

Health literacy largely determines a person's attitude to medical services, including the necessity to undergo regular medical checkups, willingness to follow medical advice, etc Research demonstrates that the primary reason why patients present to a doctor is the symptoms of a disease; however, only $24-32 \%$ of patients seek medical advice on the first day the disease starts to manifest itself. Every second responder goes to a doctor when they need a sick leave or other medical certificates. Importantly, 24-30\% of the working-age population undergo health checkups on their own initiative, but only $10-12 \%$ think it necessary to ask their doctor about disease prevention strategies. It has been established that only $64-68 \%$ of patients with chronic conditions visit their doctors regularly.

It is well known that a good night's sleep restores energy to the body and brain. However, research shows that only $10-18 \%$ of adults are not sleep-deprived. A lot of respondents (34-42\%) report sleeping less than 6 hours a night. Another important characteristic of sleep is its quality. It has been established that $42-58 \%$ of the population are satisfied with their sleep quality and duration; there are 1.4-1.8 times more women who are satisfied with their sleep than men. Women also tend to take sleeping pills 2.0-2.5 times more often than men.

Lack of sleep in teenagers is becoming a serious concern. Most of them go to bed at 22:00-23:00 (45.9\%), some go at 23:00-24:00 (35.6\%) and at 00:00-01:00 (11.5\%). The majority of university students go to sleep at 23:00-24:00 (60.7\%), some go at 00:00-01:00 (34.1\%). This means that nighttime sleep is reduced to $431.0 \pm 70.1 \mathrm{~min}$ in schoolchildren $(7 \mathrm{~h}$ on average) and $402.7 \pm 89.5 \mathrm{~min}$ (6.5 h on average) in university students [41, 42]

A lifestyle a person leads, including diet and physical exercise, affects his/her weight. Both weight excess and deficiency can trigger diseases. About half of the respondents (42-48) watch their weight; women do it more 1.5-2.0 times more often than men. Patients suffering from chronic conditions start to control their weight if their health deteriorates (20-32\%). Healthy individuals are more driven by the desire to have a slender figure (22-32\%), which is more typical for younger people than for their older counterparts. Only 25-37\% of overweight individuals try different methods of weight control, which indicates a generally low level of health literacy in the population. The survey shows that there are 1.5 more individuals $(p<0.05)$ watching their weight among those who follow medical advice.

Measures for weight control typically include new dietary regimens and physical activity. A study shows that $52-58 \%$ of adult population have bad eating habits, of them 34-38\% eat irregular meals, $26-34 \%$ eat twice a day and $23-38 \%$ consume too much bread, salt, smoked foods, sweets, etc. The comparative analysis demonstrates that there are 1.9-2.4 times more individuals following an unhealthy diet among patients with chronic conditions $(p<0.05)$ than among healthy respondents.

Lack of movement not only leads to overweight, but also causes pelvic congestion, which in turn affects reproductive health and health in general $(r=-0.418 ; m= \pm 0.0022$; $p<0.0001)$. Studies have revealed that the majority of the population (74-82\%) live a sedentary lifestyle; of them there are 1.5-2.0 times more women than men $(p<0.05)$.

Smoking is another aspect of lifestyle that seriously affect human health. Smokers constitute 28 to $43 \%$ of the population. More than half of them (54-62\%) have been smoking for 5-10 years and smoke up to 20 cigarettes a day on average. Passive smokers make up 12 to $37 \%$ of the population. On the whole, the majority of the population (both active and passive smokers) can be described as a group at risk of diseases caused by smoking. This is also true for the younger generation. Surveys show that among 15 -year old teenagers $12.7 \%$ of girls and $15.1 \%$ of boys smoke regularly; $54.6 \%$ of girls and $48.1 \%$ of boys have already had their first cigarette. Boys typically start smoking at 14, girls at 13; the earliest age disclosed in the survey was 6 and 8 years for boys and girls, respectively. Alcohol is consumed once a month or less often by $32.0 \%$ teenage boys and $29.1 \%$ girls; $64.1 \%$ of boys and $58.1 \%$ of girls do not drink alcoholic beverages. The lifestyle of boys and girls does not differ significantly, and both sexes are susceptible to bad habits and unhealthy behavioral patterns. There are significant correlations between a handgrip and smoking $(r=-0.74 ; p<0.05)$, the age when the first cigarette was tried $(r=-0.33 ; p<0.05)$, time spent in front of the computer $(r=-0,39 ; p<0.05)$, and engagement in sports $(r=0.34$; $p<0.05)$ [43].

The analysis of research works carried out at the Department of Public Health and Healthcare of Pirogov Russian National Research Medical University provided us with valuable data that was subsequently used to comprehensively assess the health awareness of the population. Based on the scored points, the respondents were distributed into 3 groups. The majority of the working-age participants (53-57\%) constituted the group with average scores; one in every five or four participants (22-26\%) represented the group of increased health risk; one in every five respondents $(18-22 \%)$ had good scores for at least $70 \%$ of the studied parameters.

Considering the importance of health awareness, prevention strategies should pay more attention to encouraging the population to seek medical information related to their health. A lot depends on the willingness of patients to maintain good health and on their convictions. Therefore, projects of medical rehabilitation should include measures that can directly affect personal lifestyle and patients should be encouraged to develop a positive attitude to medical care.

Personal commitment to a healthy lifestyle, the active contribution of the state to promoting health among its citizens, and adequate resource provision are equally important [33]. Improving health literacy is a cornerstone in stimulating patients to change their lifestyle. It will help to eradicate bad habits and turn the patient to healthy practices. Instilling willingness to lead a healthy lifestyle should become the underlying principle of disease prevention, health protection and promotion [44-46].

The works we have analyzed reveal a significant increase in health awareness and literacy in the Russian population $(r=-0.523 ; m= \pm 0.0024 ; p<0.0001)$.

\section{CONCLUSION}

Promoting hygiene and sanitation is an essential component of preventive healthcare projects that should be implemented by healthcare professionals. It includes bedside conversations 
with inpatients or conversations during home visits, lectures on health-related issues, TV or radio programs, advertisement, and educational films. Our healthcare system has sufficient resources to address the problems of disease prevention and health protection [47-50].

\section{References}

1. O nacional'nyh celjah i strategicheskih zadachah razvitija Rossijskoj Federacii na period do 2024 goda Ukaz Prezidenta RF \#204 ot 7 maja 2018 goda. Dostupno po ssylke: http://www. garant.ru/products/ipo/prime/doc/71837200/

2. O nacional'nom proekte «Zdravoohranenie». Brifing Veroniki Skvorcovoj po zavershenii zasedanija prezidiuma Soveta pr Prezidente Rossijskoj Federacii po strategicheskomu razvitiju prioritetnym proektam. Dostupno po ssylke: http://government. ru/dep_news/33207/

3. Lisicyn JuP, Polunina NV. Obshhestvennoe zdorov'e zdravoohranenie: uchebnik. M.: Medicina, 2002; 416 s.

4. Onishhenko GG. Aktual'nye zadachi gigienicheskoj nauki i praktik v sohranenii zdorov'ja naselenija. Gigiena i sanitarija. 2015; (3) 5-9.

5. Chuchalin AG, Onishhenko GG, Kolosov VP, Kurganova OP, Tezikov NL, Manakov MP. i dr. Respiratornye infekcii u detej: rezul'taty realizacii regional'noj programmy vakcinoprofilaktiki. Pediatrija. Zhurnal im. GN Speranskogo. 2016; (4): 197-202.

6. Andreeva EE, Onishhenko GG, Klejn SV. Gigienicheskaja ocenka prioritetnyh faktorov riska sredy obitanija i sostojanija zdorov'ja naselenija g. Moskvy. Analiz riska zdorov'ju. 2016; (3): 23-34.

7. Rakitskij VN. Problemy sovremennoj gigieny. Gigiena i sanitarija. 2015; 94 (4): 4-7.

8. Onishhenko GG, Rakitskij VN, Sinoda VA, Truhina GM, Lucenko LA Suhova AV. Sohranenie zdorov'ja rabotnikov pri vnedreni zdorov'e- i resursosberegajushhej tehnologii. Zdravoohranenie Rossijskoj Federacii. 2015; 59 (6): 4-8.

9. Lisicyn JuP, redaktor. Rukovodstvo po social'noj gigiene organizacii zdravoohranenija v 2 tomah. M.: Medicina, 1987 (1); $149 \mathrm{~s}$.

10. Chemezov AS. Mediko-social'noe issledovanie reproduktivnogo zdorov'ja beremennyh zhenshhin i meroprijatija po ego uluchsheniju [dissertacija]. M., 2013.

11. Avsadzhanishvili VN, Polunina NV, Polunina W. Rol' medicinsko aktivnosti $v$ formirovanii zdorov'ja detej, stradajushhih boleznjam organov dyhanija. Vestnik RGMU. 2013; (2): 70-5.

12. Karpovskij AG. Sostojanie zdorov'ja, obraz zhizni i medikosocial'naja reabilitacija naselenija starshego trudosposobnogo vozrasta [dissertacija]. M., 2006

13. Polunina NV, Pshibieva SV, Al-Garahi TA, Polunina W. Nekotorye aspekty sohranenija zdorov'ja lic mediko-social'nogo riska s pozicii gumanizma. Obshhestvennoe zdorov'e i profilaktika zabolevanij. 2007; (1): 54-9.

14. Polunina NV, Goncharova AV, Kostin AP, Kopeckij IS. Medikoorganizacionnye aspekty reabilitacii bol'nyh s vospalitel'nymi zabolevanijami i povrezhdenijami cheljustno-licevoj oblasti v ambulatornyh uslovijah. Rossijskij medicinskij zhurnal. 2010; (5): 4-8.

15. Jumukjan AV. Osobennosti sostojanija zdorov'ja i obraza zhizn junoshej-podrostkov na sovremennom jetape razvitija obshhestva. Vestnik RGMU. 2012; (1): 75-9.

16. Polunina NV, Kurcer MA, Kutakova JuJu, Chemezov AS, Cherepnina AL. Jeffektivnost' realizacii meroprijatij po sovershenstvovaniju medicinskoj pomoshhi zhenshhinam s neblagoprijatnym techeniem beremennosti. Vestnik RGMU. 2012; (6): 76-80.

17. Dubovich EG, Polunina NV, Keshishjan ES, Saharova ES. Rol psihologicheskogo sostojanija roditelej $v$ jeffektivnosti medikosocial'noj reabilitacii nedonoshennogo rebenka s tjazhelymi formami retinopatii. Rossijskij vestnik perinatalogii i pediatrii. 2012 ; 57 (1): 104-8.

18. Marks K, Jengel's F. Sochineniya. 1974; 3: 19.
Prevention is a secret to a long and healthy life. It aims at averting diseases at early, middle and old ages, increasing life expectancy, promoting positive attitude to healthy lifestyles, and creating safe environments for studying, working, and leisure activities.
19. Timerzjanov Ml, Polunina NV, Milushkina OJu, Pivovarov JuP, Polunin VS, Al Sabunchi AA i dr. Gigienicheskaja ocenka uslovij truda $\vee$ uchrezhdenijah ispravitel'noj sistemy: problemy i puti reshenija. Vestnik RGMU. 2017; (6): 42-6.

20. Agadzhanjan NA, Radysh IV. Kachestvo i obraz zhizni studencheskoj molodezhi. Jekologija cheloveka. 2009; (5): 3-8.

21. Zhaboeva SL. Organizacionno-metodicheskie osnovy modelirovanija personificirovannyh programm profilaktiki vozrastassociirovannyh zabolevanij i ocenka ih jeffektivnosti [dissertacija]. M., 2017.

22. Doronkin MV. Kompleksnoe social'no-gigienicheskoe issledovanie sostojanija zdorov'ja i organizacii medicinskoj pomoshhi sotrudnikam organov vnutrennih del [dissertacija]. M., 2007.

23. Avdeev MV. Nauchnoe obosnovanie modeli profilakticheskoj dejatel'nosti centrov zdorov'ja [dissertacija]. SPb., 2015.

24. Dubovich EG. Nauchnoe obosnovanie organizacii medikosocial'noj reabilitacii detej rannego vozrasta, rodivshihsja nedonoshennymi [dissertacija]. M., 2013.

25. Skoblina NA, Milushkina OJu, Tatarinchik AA, Fedotov DM. Gigienicheskie problemy ispol'zovanija informacionnokommunikacionnyh tehnologij shkol'nikami i studentami. Zdorov'e naselenija i sreda obitanija. 2017; 294 (9): 52-5.

26. Solomatin DV. Mediko-social'naja reabilitacija zhenshhin s narushenijami reproduktivnogo zdorov'ja (kompleksnoe social'nogigienicheskoe issledovanie) [dissertacija]. M., 2007.

27. Maksimova TM, Lushkina NP. Sostojanie zdorov'ja i problemy medicinskogo obespechenija pozhilogo naselenija. M.: PER SJe, 2012; 224 s.

28. Ziatdinov Al. Mediko-social'nye aspekty profilaktiki zabolevanij sredi chasto bolejushhih studentov medicinskogo universiteta [dissertacija]. Kazan', 2007

29. Kabochkin AA. Mediko-social'noe issledovanie zdorov'ja beremennyh, rozhenic i rodil'nic $v$ krupnom promyshlennom centre [dissertacija]. M., 2015.

30. Nevolin JuS. Nauchnoe obosnovanie organizacii raboty mezhterritorial'nogo centra zdorov'ja dlja detej [dissertacija]. M., 2016.

31. Zelionko AV. Obosnovanie organizacionno-profilakticheskih meroprijatij po sovershenstvovaniju sistemy formirovanija zdorov'esberegajushhego povedenija i uluchshenija kachestva zhizni naselenija [dissertacija]. SPb., 2007.

32. Milushkina OJu. Zakonomernosti formirovanija morfofunkcional'nyh pokazatelej detej i podrostkov $v$ sovremennyh sanitarnogigienicheskih i mediko-social'nyh uslovijah [dissertacija]. M.: 2013.

33. Maksimova TM. Sovremennoe sostojanie, tendencii i perspektivnye ocenki zdorov'ja naselenija. M.: PER SJe, 2002 ; $186 \mathrm{c}$.

34. Majorova EK. Sovremennye osobennosti zabolevaemosti detej megapolisa i puti ee snizhenija [dissertacija]. SPb., 2014.

35. Agafonov Al. Gigienicheskie osnovy ukreplenija zdorov'ja detej i podrostkov metodami fizicheskogo vospitanija [dissertacija]. Orenburg, 2015

36. Nagaev RJa. Mediko-social'nye aspekty ohrany zdorov'ja podrostkov 10-17 let na urovne sub"ekta Rossijskoj Federaci [dissertacija]. M., 2016.

37. Najdenova NE. Sovershenstvovanie organizacionnyh tehnologij profilakticheskoj pomoshhi rabotajushhemu naseleniju $v$ centre zdorov'ja [dissertacija]. M., 2016

38. Berezhnoj VG. Social'no-gigienicheskie aspekty sostojanija zdorov'ja i uslovij zhizni sel'skih zhitelej i obosnovanie meroprijatij po ih ozdorovleniju [dissertacija]. M., 2016. 
39. Tjumina OV, Mel'nikov VA. Zdorov'e zhenshhin pozdnego reproduktinogo vozrasta s besplodiem. M.: Akademija estestvoznanija, 2016; $210 \mathrm{~s}$.

40. Suharev AG, Ignatova LF, Stan WV, Shelonina OA, Cyrenova NM, Lukashova JuA. Mediko-social'naja ocenka obraza zhizni shkol'nikov. Rossijskij pediatricheskij zhurnal. 2014; (3): 37-40.

41. Skoblina NA, Milushkina OJu, Tatarinchik AA, Fedotov DM. Mesto gadzhetov v obraze zhizni sovremennyh shkol'nikov i studentov. Zdorov'e naselenija i sreda obitanija. 2017; 292 (7): 41-3.

42. Pivovarov JuP, Dagaeva ZA, Sheina NI. Izuchenie obraza zhizni uchashhihsja mediko-biologicheskih klassov goroda Moskvy. Zdorov'e naselenija i sreda obitanija. 2015; 264 (3): 13-15.

43. Milushkina OJu. Fizicheskoe razvitie i obraz zhizni sovremennyh shkol'nikov. Vestnik RGMU. 2013; (3): 68-71.

44. Kononova IV. Nauchnoe obosnovanie sovershenstvovanija organizacii medicinskoj i social'noj pomoshhi naseleniju starshe trudosposobnogo vozrasta $\vee$ sub"ekte Rossijskoj Federacii [dissertacija]. Orenburg, 2016.

45. Osykina AS. Social'no-gigienicheskaja ocenka sostojanija zdorov'ja i kachestva zhizni studentok medicinskogo VUZa Udmurtskoj respubliki [dissertacija]. M., 2016.

46. Obkin VS, Skobelcina KN, Ivanova Al. Vlijanie social'nyh faktorov na semejnyj dosug doshkol'nika. Sociologicheskie issledovanija. 2013; 350 (6): 62-70

47. Kuchma VR, Suharev AG. Gigiena detej i podrostkov kak razdel profilakticheskoj mediciny. Gigiena i sanitarija. 2015; 94 (6): 66-70.

48. Starodubov VI, Son IM, Senenko ASh, Korotkova AV, Leonov SA, Ceshkovskij MS i dr. Obshhestvennoe zdravoohranenie i formirovanie edinogo profilakticheskogo prostranstva. Menedzher zdravoohranenija. 2016; (4): 6-13.

49. Habriev RU, Kirgizova NS. Novyj kriterij ocenki obshhestvennogo zdorov'ja. Bjulleten' Nacional'nogo nauchno-issledovatel'skogo instituta obshhestvennogo zdorov'ja im. NA Semashko. 2017; (1): 303-7.

50. Bojcov SA, Samorodskaja IV, Semenov VJu. Vlijanie medicinskih i nemedicinskih faktorov na smertnost' naselenija: jekonomicheskie faktory. Problemy social'noj gigieny, zdravoohranenija i istori mediciny. 2016; 24 (6): 335-9.

\section{Литература}

1. О национальных целях и стратегических задачах развития Российской Федерации на период до 2024 года Указ Президента РФ № 204 от 7 мая 2018 года. Доступно по ссылке: http://www.garant.ru/products/ipo/prime/doc/71837200/

2. О национальном проекте «Здравоохранение». Брифинг Вероники Скворцовой по завершении заседания президиума Совета при Президенте Российской Федерации по стратегическому развитию и приоритетным проектам. Доступно по ссылке: http://government.ru/dep_news/33207/

3. Лисицын Ю. П., Полунина Н. В. Общественное здоровье и здравоохранение: учебник. М.: Медицина, 2002; 416 с.

4. Онищенко Г. Г. Актуальные задачи гигиенической науки и практики в сохранении здоровья населения. Гигиена и санитария. 2015; (3): 5-9

5. Чучалин А. Г., Онищенко Г. Г., Колосов В. П., Курганова О. П. Тезиков Н. Л., Манаков М. П. и др. Респираторные инфекции у детей: результаты реализации региональной программь вакцинопросилактики. Педиатрия. Журнал им. Г. Н. Сперанского. 2016; (4): 197-202.

6. Андреева Е. Е., Онищенко Г. Г., Клейн С. В. Гигиеническая оценка приоритетных факторов риска среды обитания и состояния здоровья населения г. Москвы. Анализ риска здоровью. 2016; (3): 23-34.

7. Ракитский В. Н. Проблемы современной гигиены. Гигиена и санитария. 2015; 94 (4): 4-7.

8. Онищенко Г. Г., Ракитский В. Н., Синода В. А., Трухина Г. М., Луценко Л. А., Сухова А. В. Сохранение здоровья работников при внедрении здоровье- и ресурсосберегающей технологии Здравоохранение Российской Федерации. 2015; 59 (6): 4-8.

9. Лисицын Ю. П., редактор. Руководство по социальной гигиене и организации здравоохранения в 2 томах. М.: Медицина, 1987; (1); 149 с.

10. Чемезов А. С. Медико-социальное исследование репродуктивного здоровья беременных женщин и мероприятия по его улучшению [диссертация]. М., 2013.

11. Авсаджанишвили В. Н., Полунина Н. В., Полунина В.В.Роль медицинской активности в формировании здоровья детей, страдающих болезнями органов дыхания. Вестник РГМУ. 2013; (2): 70-5.

12. Карповский А. Г. Состояние здоровья, образ жизни и медико-социальная реабилитация населения старшего трудоспособного возраста [диссертация]. М., 2006.

13. Полунина Н. В., Пшибиева С. В, Аль-Гарахи Т. А., Полунина В. В. Некоторые аспекты сохранения здоровья лиц медикосоциального риска с позиции гуманизма. Общественное здоровье и профилактика заболеваний. 2007; (1): 54-9.

14. Полунина Н. В., Гончарова А. В., Костин А. П., Копецкий И. С
Медико-организационные аспекты реабилитации больных с воспалительными заболеваниями и повреждениями челюстно-лицевой области в амбулаторных условиях. Российский медицинский журнал. 2010; (5): 4-8.

15. Юмукян А. В. Особенности состояния здоровья и образа жизни юношей-подростков на современном этапе развития общества. Вестник РГМУ. 2012; (1): 75-9.

16. Полунина Н. В., Курцер М. А., Кутакова Ю. Ю., Чемезов А. С., Черепнина А. Л. Эффективность реализации мероприятий по совершенствованию медицинской помощи женщинам с неблагоприятным течением беременности. Вестник РГМУ. 2012; (6): 76-80

17. Дубович Е. Г., Полунина Н. В., Кешишян Е. С., Сахарова Е. С. Роль психологического состояния родителей в эффективности медико-социальной реабилитации недоношенного ребенка с тяжелыми формами ретинопатии. Российский вестник перинаталогии и педиатрии. 2012; 57 (1): 104-8.

18. Маркс К., Энгельс Ф. Сочинения. 1974; 3: 19

19. Тимерзянов М. И., Полунина Н. В., Милушкина О. Ю., Пивоваров Ю. П., Полунин В. С., Аль Сабунчи А. А. и др. Гигиеническая оценка условий труда в учреждениях исправительной системы: проблемы и пути решения. Вестник РГМУ. 2017; (6): 42-6.

20. Агаджанян Н. А., Радыш И. В. Качество и образ жизни студенческой молодежи. Экология человека. 2009; (5): 3-8.

21. Жабоева С. Л. Организационно-методические основы моделирования персонифицированных программ просилактики возраст-ассоциированных заболеваний и оценка их эффективности [диссертация]. М., 2017.

22. Доронкин М. В. Комплексное социально-гигиеническое исследование состояния здоровья и организации медицинской помощи сотрудникам органов внутренних дел [диссертация]. М., 2007.

23. Авдеев М.В.Научное обоснование модели профилактической деятельности центров здоровья [диссертация]. СПб., 2015.

24. Дубович Е. Г. Научное обоснование организации медикосоциальной реабилитации детей раннего возраста, родившихся недоношенными [диссертация]. М., 2013.

25. Скоблина Н. А., Милушкина О. Ю., Татаринчик А. А., Федотов Д. М. Гигиенические проблемы использования информационнокоммуникационных технологий школьниками и студентами. Здоровье населения и среда обитания. 2017; 294 (9): 52-5.

26. Соломатин Д. В. Медико-социальная реабилитация женщин с нарушениями репродуктивного здоровья (комплексное социально-гигиеническое исследование) [диссертация]. М., 2007 
27. Максимова Т. М., Лушкина Н. П. Состояние здоровья и проблемы медицинского обеспечения пожилого населения. М.: ПЕР СЭ, 2012; 224 c.

28. Зиатдинов А. И. Медико-социальные аспекты профилактики заболеваний среди часто болеющих студентов медицинского университета [диссертация]. Казань, 2007.

29. Кабочкин А. А. Медико-социальное исследование здоровья беременных, рожениц и родильниц в крупном промышленном центре [диссертация]. М., 2015.

30. Неволин Ю. С. Научное обоснование организации работы межтерриториального центра здоровья для детей [диссертация]. М., 2016.

31. Зелионко А. В. Обоснование организационно-профилактических мероприятий по совершенствованию системы формирования здоровьесберегающего поведения и улучшения качества жизни населения [диссертация]. СПб., 2007.

32. Милушкина О. Ю. Закономерности формирования морфофункциональных показателей детей и подростков в современных санитарно-гигиенических и медико-социальных условиях [диссертация]. М., 2013.

33. Максимова Т. М. Современное состояние, тенденции и перспективные оценки здоровья населения. М.: ПЕР СЭ, 2002; 186 c.

34. Майорова Е. К. Современные особенности заболеваемости детей мегаполиса и пути ее снижения [диссертация]. СПб. 2014.

35. Агафонов А. И. Гигиенические основы укрепления здоровья детей и подростков методами физического воспитания [диссертация]. Оренбург, 2015.

36. Нагаев Р. Я. Медико-социальные аспекты охраны здоровья подростков 10-17 лет на уровне субъекта Российской Федерации [диссертация]. М., 2016.

37. Найденова Н. Е. Совершенствование организационных технологий просилактической помощи работающему населению в центре здоровья [диссертация]. М., 2016.

38. Бережной В. Г. Социально-гигиенические аспекты состояния здоровья и условий жизни сельских жителей и обоснование мероприятий по их оздоровлению [диссертация]. М., 2016.

39. Тюмина О. В., Мельников В. А. Здоровье женщин позднего репродуктиного возраста с бесплодием. М.: Академия естествознания, 2016; 210 с.
40. Сухарев А. Г., Игнатова Л. Ф., Стан В. В., Шелонина О. А., Цыренова Н. М., Лукашова Ю. А. Медико-социальная оценка образа жизни школьников. Российский педиатрический журнал. 2014; (3): 37-40.

41. Скоблина Н. А., Милушкина О. Ю., Татаринчик А. А., Федотов Д. М. Место гаджетов в образе жизни современных школьников и студентов. Здоровье населения и среда обитания. 2017; 292 (7): 41-3.

42. Пивоваров Ю. П. Дагаева З. А., Шеина Н. И. Изучение образа жизни учащихся медико-биологических классов города Москвы. Здоровье населения и среда обитания. 2015; 264 (3): 13-15.

43. Милушкина О. Ю. Физическое развитие и образ жизни современных школьников. Вестник РГМУ. 2013; (3): 68-71.

44. Кононова И. В. Научное обоснование совершенствования организации медицинской и социальной помощи населению старше трудоспособного возраста в субъекте Российской Федерации [диссертация]. Оренбург, 2016.

45. Осыкина А. С. Социально-гигиеническая оценка состояния здоровья и качества жизни студенток медицинского ВУЗа Удмуртской республики [диссертация]. М., 2016.

46. Обкин В. С., Скобельцина К. Н., Иванова А. И. Влияние социальных факторов на семейный досуг дошкольника. Социологические исследования. 2013; 350 (6): 62-70.

47. Кучма В. Р., Сухарев А. Г. Гигиена детей и подростков как раздел профилактической медицины. Гигиена и санитария. 2015; 94 (6): 66-70.

48. Стародубов В. И., Сон И. М., Сененко А. Ш., Короткова А. В. Леонов С. А., Цешковский М. С. и др. Общественное здравоохранение и формирование единого просилактического пространства. Менеджер здравоохранения. 2016; (4): 6-13.

49. Хабриев Р. У., Киргизова Н. С. Новый критерий оценки общественного здоровья. Бюллетень Национального научноисследовательского института общественного здоровья им. Н. А. Семашко. 2017; (1): 303-7.

50. Бойцов С. А., Самородская И. В., Семенов В. Ю. Влияние медицинских и немедицинских факторов на смертность населения: экономические факторы. Проблемы социальной гигиены, здравоохранения и истории медицины. 2016; 24 (6): 335-9. 